zam i u borbu za ženska prava nije bila ni jednostavna niti linearna, a ni potpuno slobodna. U permanentnom pregovaranju i balansiranju između privatnog i javnog, proklamiranog i realnog, tradicije i modernosti, te žene iznose svoja iskustva i stavove o poziciji žena u obitelji (primarnoj i sekundarnoj), osobnom muslimanskom identitetu, važnosti religije i duhovnosti tijekom života, ulozi religije $u$ javnom životu te neizbježnom hidžabu, obrazovanju i osobnom viđenju feminizma, vlastitom aktivizmu ...

Knjigu zaokružuju Zaključak, Prilog 1. Istraživački uzorak te Glosar, koji daje informacije o ključnim pojmovima iz islamske tradicije. U konačnici možemo zaključiti da je knjiga Propitivanje ženskih, feminističkih i muslimanskih identiteta. Postsocijalistički konteksti u Bosni i Hercegovini i na Kosovu vrlo važna i aktualna knjiga jer daje velik doprinos - i teorijski i empirijski propitkivanju identiteta, religije, etniciteta i feminizma te omogućuje kompleksan uvid u raznolikosti ženskih iskustava i rodnih strategija. Uz to, ova knjiga baca novo svjetlo na odnos feminiz(a)ma i islama, pokazujući da se ta dva životna opredjeljenja mogu dopunjavati, čime se demantiraju vulgarne i redukcionističke interpretacije ženskoga pitanja u islamu i predrasude o feminizmu. Kao i u ranijim radovima Zilke Spahić-Šiljak, i u ovoj je knjizi očito promoviranje polikovalnosti i tolerancije, kao i permanentna težnja urednice za transcendiranjem konfliktnosti između vjerske i civilne sfere, javne i privatne sfere te zagovaranje prijelaza s puke deklarativne razine u sferu konkretnoga, angažiranog djelovanja.

Marija Geiger Zeman

\section{doi:10.5559/di.21.2.16 \\ Richard Arena, Sheila Dow, Matthias Klaes (Ur.) OPEN ECONOMICS ECONOMICS IN RELATION TO OTHER DISCIPLINES}

Routledge, London and New York, 2009., 349 str.

Ekonomska znanost danas zauzima posebno mjesto među društvenim znanostima. Matematička metodološka osnova neoklasične ekonomije - dominantne paradigme suvremene ekonomske analize - stavlja ekonomsku znanost na pijedestal egzaktnosti ravan prirodnim znanostima. $U$ takvoj je konstelaciji matematička metodološka osnova uvelike marginalizirala druge pristupe ekonomskoj disciplini. S druge pak strane, mnogo tržišnih podbačaja te praktičnih odstupanja od teorijski zamišljenih koncepata otvaraju prostor i drugačijem analitičkom pristupu. $\mathrm{Na}$ takvu intelektualnu raskrižju nastaje knjiga "Open Economics - Economics in relation to other disciplines", zapravo tematski zbornik radova više autora o temi granica ekonomske znanosti i njezinih dodirnih točaka s drugim znanstvenim disciplinama.

Sadržajno podijeljena u šest eklektičkih poglavlja, "Open Economics" stavlja ekonomiju u odnos prema humanističkim i prirodnim znanostima: matematici, arhitekturi, geografiji te na koncu sociologiji. Pritom nemajući za cilj sistematizirati sveukupnost odnosa ekonomije s drugim znanstvenim disciplinama i intelektualnim idejama, presjek obrađenih tema tek je partikularan uvid u svaki pojedini odnos te poziva na daljnje razmišljanje i analizu. Pritom je pozicija autora uvijek kritička, tako da otvara vrata novim uvidima ili naglašavajući nedorečenosti dominantne paradigme.

U prvom poglavlju razmatraju se tri teme odnosa ekonomije s humanističkim i 
društvenim znanostima. Autori tako uočavaju dvojak utjecaj književnosti na ekonomsku disciplinu: kroz opis slike povijesnog razdoblja i "duha vremena" u kojem su se razvijale ekonomske ideje te kroz psihološku složenost aktera književnoga djela nasuprot pojednostavnjenom ekonomskom akteru. Kad je Daniel Kahneman 2002. primio Nobelovu nagradu iz ekonomije za rad na odnosu psihologije i ekonomije, mnoga su očekivanja išla u smjeru sve veće afirmacije kognitivne, odnosno bihevioralne, ekonomije.

U raspravi na kraju poglavlja stoga se govori o povijesnim korijenima utjecaja psihologije na ekonomiju. Autori pozivaju na preispitivanje hedonističke i utilitarističke filozofije te njihova odnosa s političkom ekonomijom. Tako, primjerice, tvrde da je Kahnemanovo pozivanje "natrag na Benthama" anakronizam, jer ne uzima u obzir rad Pietra Verrija, ekonomista Milanske škole političke ekonomije, a upravo su njegove ideje ključno utjecale na Benthama. U drugom se poglavlju razmatra odnos ekonomije prema prirodnim znanostima i životu. Česte usporedbe ekonomije s fizikom na temelju sličnosti metodološkoga pristupa, s obzirom na formaliziranost analize i zahtijevanu egzaktnost rezultata, zapravo nisu jednostavne. Vrlo su često ekonomske posudbe metodoloških alata iz fizike manje svjesne i promišljene nego što se to u prvi mah čini. Nerijetko su i povijesni obrati u filozofskom shvaćanju svijeta jednako snažno odjeknuli na fiziku i političku ekonomiju vremena simultano. Tako se, primjerice, u eseju o "Newtonovoj fizici i oblikovanju političke ekonomije" raspravlja o idejnoj sintezi Smithova Bogatstva naroda. Autori tvrde kako je njutnovska filozofija zapravo bila izlaz škotske filozofije iz postreformacijskog ra- cionalizma, s jedne strane, i skepticizma šesnaestoga stoljeća, s druge. Smith je, zaključuje se, prihvatio Newtona upravo sastavljajući svoje epohalne uvide o Bogatstou naroda.

Druga rasprava ovoga poglavlja povezuje Veblena i evolucijsku biologiju. Otkako je Veblen svojom britkom kritikom "upadljivoga trošenja" razotkrio motivacijsku prostodušnost klase koja je sebe smatrala biološki predodređenom da vlada, nitko od bogataša onoga vremena zacijelo nije više tako lagodno pokazivao društveni status. U pozadini je, naravno, ležala bitno dublja logika, u kojoj je Veblen svoj model ljudskoga "instinkta i navike" praktički primijenio na društvenu sliku svoga vremena.

U zadnjoj raspravi autori tvrde kako se ljudsko shvaćanje svijeta u povijesti vrlo često izjednačivalo sa shvaćanjem ljudskoga organizma. Stoga ne bi trebala čuditi brojnost semantičkih posudbi ekonomske znanosti iz medicinske terminologije čak i u suvremenoj ekonomiji pojmovi poput "cirkulacije novca" figuriraju kao pons asinorum u obrazovanju ekonomista.

Možda je najkontroverznije metodološko pitanje moderne ekonomije odnos ekonomije s matematikom. U trećem se poglavlju razmatra upravo taj odnos. $\mathrm{Ne}$ postoji a priori razlog da teorijska logičnost matematički opisanih relacija bude konzistentna s primjenom takvih modela na društvenu stvarnost. Stoga je matematiziranje $u$ društvenim znanostima uvijek podložno pitanju koliko su takvi modeli objektivni, osobito u vremenu u kojem i sama kompleksnost društvene arhitekture prijeti njezinu kolapsu.

U raspravi o "Osnovi matematike kao predlošku za neoklasičnu ekonomiju" postavlja se pitanje je li moguće znanstveno osnovano zaključiti o "ovome svijetu" na temelju modela kojega su premise u "vanjskom svijetu" matematičkih zakonitosti. Mogu li se takve pretpostavke kasnije eksperimentalno provjeriti $u$ znanosti koja je $u$ praktičnom smislu neeksperimentalna? Ako se ne može nedvosmisleno odgovoriti na ovakvu vrstu ključnih upita, je li u konačnici razložno prihvatiti matematiku kao 
osnovu dominantne paradigme $\mathrm{u}$ ekonomiji? Radna hipoteza treba biti preciznije formulirana: koji je najbolji način primjene matematike $\mathrm{u}$ ekonomiji?

$\mathrm{Na}$ kraju, autori predlažu metodološki test o opravdanosti matematičke analize u društvenim znanostima: prema nizu Daubert zakonskih slučajeva američkoga Vrhovnog suda, određeno znanje može biti potvrđeno kao znanstveno ako zadovoljava pet kriterija: 1 . može se testirati, 2. dovoljno je publicirano, 3. poznat je stupanj moguće pogreške, 4 . postoje standardi kontrole, 5. široko je prihvaćeno. U logičnom nastavku ove rasprave poglavlje se zaključuje razmatranjem debate J. M. Keynesa i J. Timbergena o opravdanosti ekonometrije kao testa ekonomske teorije. Keynes je bio skeptičan prema prognostičkoj pouzdanosti ekonometrijskih procjena zbog nestabilnosti sistema na duge staze te utjecaju eksternih šokova, što su nedavna zbivanja na financijskim tržištima ponovno potvrdila.

$\mathrm{U}$ četvrtom poglavlju autori isprepleću teorijske i praktične aspekte međuodnosa ekonomije i arhitekture. Ekonomski i arhitektonski projekti dijele slično problematsko polazište: ograničenja ekonomskih aktera i modela moraju biti u skladu s postavkom o njihovoj racionalnosti baš kao što arhitektura uvijek mora zadovoljiti umjetnički kriterij uz uvjet racionalne kalkulacije projekta. Povijesni razvoj ovih dviju disciplina također je slijedio usporedivu paralelu. Praktična primjena arhitektonskih rješenja urbanog razvoja u Latinskoj Americi druga je tema u ovome poglavlju. Pritom se upozorava na niz interdisciplinarnih znanja koja moraju biti optimalno ugrađena u takve projekte kako bi oni ostvarili očekivane rezultate te je naglašena važnost pristupa konkretnom problemu nasuprot univerzalnim principima neolibe- ralizma.

Kao prilog sve većem broju suprotstavljenih teorija o globalizaciji i globalnoj raspodjeli bogatstva, u poglavlju o odnosu ekonomije i geografije $u$ raspravu se $u$ vodi pojam prostora. Autori zauzimaju stav da shvaćanje prostora u ekonomiji vrlo ovisi o analitičkom polazištu. Neoklasična teorija rasta promatra siromaštvo i nerazvijenost kao kratkoročni fenomen nastao zbog izostanka primjene tržišnih principa. Maršalijanski pristup promatra prostor kao organizacijski institucionalno i mrežno određen. Konkurentnost tako proizlazi iz lokalnih uvjeta i prilika.

Marksistička perspektiva promatra globalizaciju i prostor kao kapitalu podređene čimbenike. Globalizacija je stoga funkcija dominacije interesa kapitala nad radom, a neravnomjeran razvoj svjetske ekonomije rezultat je interakcije prostorne podjele radne snage i globalnih tokova kapitala u potrazi za najvišim prinosom. $U$ kontekstu biografije W. Pettyja, druga rasprava povezuje njegove prve prostorno-ekonomske izračune s osnovama formalističke metodologije suvremene prostorne ekonomije, koja svoju afirmaciju dokazuje i dodjelom Nobelove nagrade za ekonomiju 2008. godine P. Krugmanu za uvide u teoriju nove ekonomske geografije tj. razmjene.

U socioekonomskoj raspravi zadnjega poglavlja o uzrocima njemačkoga zastranjivanja u nacistički totalitarizam autori pokazuju da "društvo nije fiksna varijabla", kako to često smatra neoklasična teorija. Na temelju G. Schmollerove i W. Sombartove ekonomske sociologije zaključuje se da su zakašnjela njemačka industrijalizacija i kidanje tradicionalnih društvenih veza rezultirali intelektualnim strahom od "dominacije ekonomskog" te prizivanjem snažne države koja bi takve procese ublažila, vodeći, na kraju, njemačku naciju prema nacističkoj ideologiji.

U posljednjoj se raspravi propitkuje radna teza neoklasične ekonomske teorije o racionalnosti ekonomskih aktera. Tvrdi se da osnove na kojima je postavljen dru- 
štveni poredak $\mathrm{u}$ neoklasičnim modelima jednostavno nisu održive uz uključivanje realistične pretpostavke o djelovanju ekonomskih aktera na temelju nealtruističnih, nemaksimizirajućih i, riječju, neracionalnih motiva.

Polazeći od ideje da epistemološka izolacija u ekonomiji dovodi do znatnih spoznajnih redukcija, do neispravna metodološkoga pristupa i, na kraju, do pogrešna "policy outputa", ova je knjiga prilog pluralističkom shvaćanju ekonomije. Pisana u eruditskoj maniri heterodoksnoga pristupa ekonomiji, "Open Economics" problematizira neoklasičnu analizu u ekonomiji na dvije fronte - na povijesnoj i na metodološkoj. Naglašavajući redovito povijesni kontekst nastanka i međudjelovanja ekonomske misli sa širom znanstvenom misli i praksom, poglavlja sukcesivno zaokružuju ideju ekonomije kao otvorene discipline u sučeljavanju s drugim znanstvenim područjima.

Luka Šikić

\section{doi:10.5559/di.21.2.17 \\ Dragoljub B. Dorđević NA KONJU 5 LAPTOPOM U BISAGAMA Uvod 0 romološke studije}

Mašinski fakultet Univerziteta u Nišu, Prometej, Novi Sad, 2010., 464 str.

Knjiga Na konju s laptopom u bisagama niškoga sociologa religije i romologa Dragoljuba B. Đorđevića objavljena je u 2010. u izdanju Mašinskoga fakulteta Univerzite- ta u Nišu i nakladničke kuće Prometej. Knjiga ima 464 stranice i sastoji se od sedam poglavlja naslovljenih: Srž romologije, Romska umešnost preživljavanja, Stradanje $i$ žigosanje Roma, Verski život Roma, Kultna mesta Roma, Kultura smrti Roma, Akademski položaj romologije, unutar kojih autor nastoji rasvijetliti temeljne karakteristike romske kulture.

U prvom poglavlju naslovljenom Srž romologije autor donosi prikaz temeljnih karakteristika romologije, koju - slijedeći sociologa i romologa Rajka Đurića - definira kao znanstvenu disciplinu kojoj je predmet proučavanje Roma i njihov život, odnosno skupine ljudi koji po svojem etničkom i povijesnom podrijetlu, socijalnim, kulturnim, jezičnim i drugim karakteristikama te povijesnoj sudbini i svijesti čine posebnu društvenu zajednicu. Razmatrajući ishodišta romologije i njezine bitne karakteristike, autor navodi etnologiju kao majku romologije, pri čemu, s jedne strane, ističe njezino pozitivno značenje za razvoj znanstvenoga proučavanja Roma i njihova života, dok s druge strane upozorava na nedostatnost isključivo etnološkoga pristupa za cjelovito razumijevanje života i kulture Roma. Upravo stoga, autor inzistira na interdisciplinarnom karakteru romologije, stavljajući tako poseban naglasak na potrebu prožetosti i suradnje raznih znanstvenih disciplina kako bi se shvatio život i položaj Roma, pri čemu posebno naglašava potrebu proučavanja Roma i njihova života iz sociološke perspektive. Govoreći o temeljnim postavkama romologije, autor kao bitne karakteristike romske zajednice ističe praktičnu interkulturalnost Roma, pod čime razumijeva otvorenost romske zajednice prema drugima te njihov položaj etnoklase. Naime, polazeći od Weberova modela socijalne stratifikacije, autor zaključuje kako se radi o etničkoj zajednici koja u svim društvima živi na granici ili ispod granice apsolutnoga siromaštva i koju karakterizira minimum ugleda i moći u društvu. Poboljšanje položaja Roma, po autorovu mišljenju, moguće 